\title{
Ecological constraints on planktonic nitrogen fixation in saline estuaries. I. Nutrient and trophic controls
}

\author{
Roxanne Marino ${ }^{1,2, *}$, Francis Chan ${ }^{1,3,4}$, Robert W. Howarth ${ }^{1,2}$, Michael L. Pace ${ }^{3}$, \\ Gene E. Likens ${ }^{3}$ \\ ${ }^{1}$ Department of Ecology \& Evolutionary Biology, Cornell University, Ithaca, New York 14853, USA \\ ${ }^{2}$ The Ecosystems Center, Marine Biological Laboratory, Woods Hole, Massachusetts 02543, USA \\ ${ }^{3}$ Institute of Ecosystem Studies, Millbrook, New York 12545, USA \\ ${ }^{4}$ Present address: Department of Zoology, Cordley Hall, Oregon State University, Corvallis, Oregon 97331, USA
}

\begin{abstract}
Heterocystous, planktonic cyanobacteria capable of fixing atmospheric $\mathrm{N}_{2}$ into available nitrogen $(\mathrm{N})$ are common and critically important to nutrient cycling in many lakes, yet they are rarely observed in estuaries at salinities $>10 \mathrm{ppt}$, even when strongly $\mathrm{N}$ limited. In a series of mesocosm experiments using water from Narragansett Bay (Rhode Island), we manipulated top-down (grazing) and bottom-up (nutrient) factors hypothesized to exclude heterocystous cyanobacteria from estuaries. We previously reported that planktonic, heterocystous cyanobacteria grew and fixed $\mathrm{N}$ in the absence of grazers. Here, we focus on responses to phosphorus (P) additions and grazer manipulations. Zooplankton (Acartia sp.) populations typical of temperate zone estuaries suppressed cyanobacteria, and their influence was direct through grazing rather than indirect on nutrient stoichiometry. Cyanobacterial abundance and heterocysts were low in treatments with no external $\mathrm{P}$ inputs. Concentrations of dissolved inorganic P comparable to those in Narragansett Bay were obtained only in P-fertilized mesocosms. Unlike previous estuarine mesocosm experiments with P fertilization, planktonic cyanobacteria grew and fixed $\mathrm{N}$ in our experimental systems. However, mean cell and heterocyst abundances under the most favorable conditions (high $\mathrm{P}$, low $\mathrm{N}: \mathrm{P}$, and low grazers) were much lower than in comparable freshwater experiments, with $\mathrm{N}$ limitation maintained. These results support the hypothesis that intrinsic growth of heterocystous cyanobacteria in saline estuaries is slower than in freshwater, and that slower growth is unlikely to be due to systematic differences in P availability. Slow growth, combined with grazing, can severely limit development of planktonic, N-fixing cyanobacterial blooms in estuaries.
\end{abstract}

KEY WORDS: Nitrogen fixation · Heterocystous cyanobacteria $\cdot$ Estuaries $\cdot$ Nitrogen limitation · Nitrogen and phosphorus stoichiometry $\cdot$ Zooplankton grazing $\cdot$ Mesocosms

\section{INTRODUCTION}

Cyanobacterial blooms are common in many freshwater lakes, where nitrogen $(\mathrm{N})$ fixation by these organisms helps to maintain phosphorus (P) limitation of primary productivity (Schindler 1977, Howarth et al. 1988a, Hyenstrand et al. 1998). Cyanobacteria (primarily Trichodesmium sp.) also commonly fix $\mathrm{N}$ in tropical and subtropical oceanic waters, helping to maintain a close balance between $\mathrm{N}$ and P limitation over decades and longer (Karl et al. 2002). Recent evidence suggests that picoplankton also may be important $\mathrm{N}$ fixers in these oligotrophic areas (Zehr et al. 2001). In sharp contrast, $\mathrm{N}$-fixing cyanobacteria are rarely observed in the plankton of estuaries even though most temperate zone estuaries are strongly N limited (Fogg 1987, 
Howarth et al. 1988a,b, 1999, Paerl 1996, NRC 2000, Paerl \& Zehr 2000). As McCarthy (1980) observed, 'the phytoplankton capable of $\mathrm{N}_{2}$ fixation are relatively common in fresh water, scarce in the open sea and virtually unknown in estuaries.' Blooms of heterocystous cyanobacteria that can fix $\mathrm{N}$ have been reported in some nutrient-enriched estuaries and coastal seas, such as the Baltic Sea, at relatively low salinities (Lindahl \& Wallstrom 1985, Sellner 1997, Stal et al. 2003) and in a few shallow, highly eutrophic estuaries in Australia and South America, where blooms begin when the estuaries are largely fresh or exhibit very low salinity and persist as salinity increases (Huber 1986, Jones et al. 1994, Sellner 1997, Pérez et al. 1999). However, blooms of heterocystous N-fixing cyanobacteria have not been reported in any estuarine systems where salinities are persistently $>10$ to $12 \mathrm{ppt}$ (Howarth et al. 1988a,b, NRC 2000).

The virtual absence of heterocystous cyanobacteria from the plankton of higher-salinity, nutrient-enriched estuaries with a low availability of $\mathrm{N}$ relative to $\mathrm{P}$ is surprising, as rivers provide a source of these organisms, and heterocystous cyanobacteria can grow and fix $\mathrm{N}$ at high salinities in cultures and in saline lakes (Marino et al. 1990, 2003, Moisander et al. 2002a). Benthic and epiphytic cyanobacteria are found in shallow estuaries across a broad range of salinity conditions (Carr \& Whitton 1982, Howarth et al. 1988a,b, Paerl 1996), providing another source for planktonic populations in estuaries, further indicating that salinity alone does not prevent their growth.

The most likely controls for the relative lack of planktonic $\mathrm{N}$ fixation in estuaries are those that constrain initial development of a cyanobacterial population (Howarth et al. 1999), rather than factors such as light availability, dissolved organic carbon (DOC) concentrations, or partial pressure of $\mathrm{CO}_{2}\left(\mathrm{pCO}_{2}\right)$, which often change as a bloom progresses and may provide positive feedbacks for blooms in freshwater (Paerl 1996, Hyenstrand et al. 1998). The concentration of $P$ and the N:P ratio can be important controls on the initiation of $\mathrm{N}$-fixing cyanobacterial blooms in freshwater lakes (Schindler 1977, Howarth et al. 1988b) and lowsalinity regions of the Baltic Sea (Niemi 1979, Moisander et al. 2003).

We have hypothesized that the development of blooms of heterocystous $\mathrm{N}$-fixing cyanobacteria is severely limited in saline estuaries, due to an interaction of grazing mortality with slow growth rates at sulfate concentrations typical of these estuaries, rather than any single, causal mechanism (Howarth et al. 1999, Marino et al. 2002, 2003). The general absence of planktonic, N-fixing cyanobacteria from saline estuaries has created limited opportunities for manipulative tests of possible factors that constrain their growth and
$\mathrm{N}$-fixing activity. Here, we report on the results from experimental mesocosms, testing the effects of nutrient availability and grazer pressure on seasonal, cyanobacterial blooms in estuaries.

Between 1994 and 1998, we ran mesocosm experiments using estuarine water from Narragansett Bay (Rhode Island, USA, 27 to 32 ppt salinity). We have previously summarized the mean responses of 2 of these experiments, in which heterocystous cyanobacteria (Anabaena spp.) were able to grow at high salinities when zooplankton grazing pressure was low and $\mathrm{P}$ availability was high (Marino et al. 2002, 2003). Here, we emphasize the effects of grazing in the context of $\mathrm{N}$ and $\mathrm{P}$ biogeochemistry and compare responses of heterocystous cyanobacteria in seawater mesocosms to $\mathrm{N}$-fixing cyanobacteria in freshwater experimental systems that received comparable $\mathrm{P}$ loads. The $\mathrm{P}$ additions in our experiments paralleled whole-lake manipulations at the Experimental Lakes Area (ELA, Schindler 1977, Findlay et al. 1994) and a mesocosm experiment at Oneida Lake, NY (Howarth et al. 1993). A companion paper (Chan et al. 2006, this issue) further explores phytoplankton-zooplankton interactions in the mesocosms and mechanisms whereby zooplankton grazing suppresses cyanobacterial growth in estuaries.

\section{MATERIALS AND METHODS}

Mesocosm and site description. We ran 3 experiments, 1 each in the summers of 1994, 1996, and 1998, with 10 to 16 mesocosms in each experiment. The experiments were conducted outdoors on the shore of Narragansett Bay and were run from the last week of June until early September. Mesocosms were $1.83 \mathrm{~m}$ diameter, $1.15 \mathrm{~m}$ deep $\left(3 \mathrm{~m}^{3}\right.$ total volume) cylindrical tanks of Kalwal fiberglass covered with opaque insulation; tank surfaces were left open to the atmosphere. Mesocosms were gently bubbled with air to prevent stratification. Turbulent mixing intensity was estimated for the tanks using a Marsh-McBirney Model 523 electromagnetic, 2-dimensional current meter, as described in Howarth et al. (1993). Energy dissipation averaged $0.008 \mathrm{~mW} \mathrm{~kg}^{-1}$ (range 0.001 to $0.03 \mathrm{~mW}$ $\left.\mathrm{kg}^{-1}\right)$, corresponding to the lower range of values measured in identical tanks where turbulence was manipulated (Howarth et al. 1993) and within the range estimated for Narragansett Bay $\left(0.025 \mathrm{~mW} \mathrm{~kg}^{-1}\right)$ and other natural systems (Howarth et al. 1993).

New tanks were scrubbed, rinsed, and filled with seawater to leach before use. Tanks were filled with water from 2 to $3 \mathrm{~m}$ above the bottom of Narragansett Bay using a centrifugal vortex pump with a screened intake. Water was pumped through a $5 \mathrm{~cm}$ PVC pipe into a header tank and then gravity fed to the meso- 
cosms through hoses that were rotated at 5 min intervals among tanks. Complete filling of the mesocosms took from 1 to $1.5 \mathrm{~d}$ and spanned 3 to 4 tidal cycles. Experiments were run in batch mode, with no further introduction of bay water, except for that added in small amounts as a cyanobacterial 'seed' source (see below). The batch design was chosen to provide favorable physical conditions for slow-growing cyanobacteria. Each experiment lasted 2 to 2.5 mo, making the water residence time in the tanks approximately twice that of Narragansett Bay (Nixon et al. 1995). No sediments were added to the tanks. To minimize periphyton growth, sidewalls were scrubbed every 1 to $2 \mathrm{~d}$. Each tank had a dedicated scrub brush as well as sampling tube and sample-receiving bucket to prevent cross-contamination. Floating particulate material produced within the tanks was removed periodically, rinsed, and stored frozen until analyzed. Additional details are given in Marino (2001).

An important requirement for these experiments was a source of heterocystous cyanobacteria to seed the tanks. We previously observed small numbers of Anabaena filaments with heterocysts in water fed to experimental seagrass lagoons at the same site. This water was drawn from Narragansett Bay and recirculated over a macroalgal 'nutrient scrubber' bed designed to lower concentrations of $\mathrm{N}$ and $\mathrm{P}$ below those in ambient bay water (Taylor et al. 1995). The heterocystous cyanobacteria were likely present in this scrubber system, associated with the macroalgae. We set up a macroalgal bed similar in design to generate the 'seed' water used in all 3 mesocosm experiments. Narragansett Bay water pumped into a 7001 holding tank was circulated with a diaphragm pump over an algal bed continuously for 1 wk and subsequently added in small volumes (20 l) to our experimental tanks. For all treatments in all 3 mesocosm experiments, this 201 cyanobacterial 'seed' was added once per week to each tank.

Light extinction was measured using a LiCor LI1935A 4 pi sensor and LI-1000 data logger. Values ranged from $80 \%$ of surface photosynthetically active radiation (PAR) reaching tank bottoms early in the experiment to a minimum of 40 to $50 \%$ of surface irradiance (700 to $1400 \mu \mathrm{E} \mathrm{m} \mathrm{m}^{-2} \mathrm{~s}^{-1}$ on a clear mid-August day) in the tanks with the highest phytoplankton biomass. Temperature and salinity were monitored in each tank daily. Mean salinities for the 3 experiments were very similar $(32 \pm 0.6 \mathrm{ppt}$ in $1994,31.2 \pm 0.8 \mathrm{ppt}$ in 1996 , and $29.3 \pm 1.5 \mathrm{ppt}$ in 1998). Mean temperatures were also quite similar $\left(26.4 \pm 3.5^{\circ} \mathrm{C}, 24.9 \pm 1.8^{\circ} \mathrm{C}\right.$, and $26.2 \pm 3^{\circ} \mathrm{C}$ in 1994,1996 , and 1998 , respectively) and were approximately 2 to $3^{\circ} \mathrm{C}$ higher than average July and August temperatures in Narragansett Bay (Durbin \& Durbin 1981).
Experimental design. Expt 1 (1994) tested whether planktonic, heterocystous cyanobacteria could be stimulated by creating strong $\mathrm{N}$-limited conditions (low N:P) while mortality, due to zooplankton grazing, was kept low by adding zooplanktivorous fish (Menidia beryllina). A total of 5 replicate tanks each were used for no-fertilization (Control) and P-addition (+P) treatments; 15 juvenile Menidia ( 2 mo old, $2.5 \mathrm{~cm}$ long) were added to each tank. Fish biomass density was scaled to that of zooplanktivorous fish used in the freshwater pond and mesocosm experiments (Schaffner et al. 1994, Howarth et al. 1993). $\mathrm{P}$ was added twice per week as a phosphoric acid solution at a loading rate of $160 \mu \mathrm{mol} \mathrm{P} \mathrm{m} \mathrm{m}^{-3} \mathrm{~d}^{-1}$; no $\mathrm{N}$ was added. This fertilization level was used in earlier freshwater mesocosm experiments with large blooms of N-fixing, heterocystous cyanobacteria (Howarth et al. 1993). Mesocosms were fertilized 2 to $3 \mathrm{~d}$ before sampling for water chemistry. Algal material and detritus accumulated on the bottoms of all tanks during the experiment, and were removed and collected twice, on Day 28 and at the end of the experiment, by either siphoning or pumping the material through a $250 \mu \mathrm{m}$ pore polyethylene sieve into the clean bucket used for water chemistry. The water was immediately returned to the tank, and the particulate matter collected on the sieve was rinsed, placed in bags, and frozen.

Expt 2 (1996) tested the effect of 3 grazing treatments, with 4 replicates for each treatment. The zooplankton-grazing treatment (Gr) had no fish added. The no-zooplankton-grazing treatment (NGr) had zooplanktivorous fish added, as in 1994. A third treatment (+Mussels) had zooplanktivorous fish and blue mussels Mytilus edulis to test the effect of a benthic grazer. Mussels (35 to $45 \mathrm{~mm}$ long) were collected locally and suspended $\sim 0.35 \mathrm{~m}$ below the surface in plastic cages, at a density of 7 animals tank ${ }^{-1}$. This density corresponded roughly to a clearance rate of $10 \%$ of the water volume per day, a reasonable value for Narragansett Bay (Tracey 1988). All treatments were fertilized with $\mathrm{P}$ and seeded for cyanobacteria as in Expt 1. Copepod densities were low in the water used to fill the tanks, so mesozooplankton (>100 $\mu \mathrm{m}$, predominantly Acartia tonsa) were added to all 12 mesocosms on 8 July at a density of $\sim 7000$ animals $\mathrm{m}^{-3}$. These zooplankton were concentrated from tanks established to rear zooplankton collected from Narragansett Bay (Chan et al. 2006). Two weeks after filling and again at the end of the experiment, the bottoms of the mesocosms were cleaned as described for Expt 1 to remove accumulated material. Algal surface floc was removed every other day using a net, rinsed, and frozen for later analysis. Individual floc samples for each tank were pooled over time. 
Expt 3 (1998) was a $2 \times 2$ factorial test of the hypothesis that an interaction between grazing and slow growth due to low availability of molybdenum (Mo) controls the development of heterocystous cyanobacterial populations in estuaries. Each treatment had 4 replicates, totaling 16 experimental tanks. The factorial treatments were: (1) with and without zooplanktivorous fish (NGr and Gr, respectively) and (2) with and without added Mo. The Mo addition, reported in Marino et al. (2003), had a relatively small effect on the cyanobacterial growth that was only apparent in the low-grazing mesocosms. Here, we report only on the effects of the grazer manipulations, so this experiment collapses into the same design as Expt 2, but with 8 treatment replicates. Fish (NGr) and P (all tanks) were added as in Expt 2. Procedures for cleaning tank bottoms, removing algal surface floc, and supplementing zooplankton followed Expt 2.

Routine sampling procedures and methods. Stoppered, $1 \mathrm{~m}$ long PVC tubes (0.038 $\mathrm{m}$ diameter) were used for integrated water-column sampling (Howarth et al. 1993). Mesocosms were sampled weekly. For each sample, water was emptied into the clean bucket then poured into a $1 \mathrm{l}$ sampling bottle that was placed in a cooler (no ice). Care was taken to prevent contamination among mesocosms by having sampling gear designated specifically to each tank and by careful cleaning and rinsing of equipment after every use. Within 1 to $2 \mathrm{~h}$, samples were processed as follows: (1) duplicate $100 \mathrm{ml}$ aliquots were preserved with acid Lugol's (Wetzel \& Likens 2000) in glass bottles and stored in the dark until counted, (2) a $100 \mathrm{ml}$ aliquot in a polyethylene bottle was frozen for later analysis of total $\mathrm{N}$ and total P (TN, TP), (3) a 250 to $350 \mathrm{ml}$ aliquot was filtered at low vacuum through a glass fiber filter $(\mathrm{GF} / \mathrm{F}, 0.7 \mu \mathrm{m}$ nominal pore size) directly into a polypropylene receiving bottle (1 for each tank). The filter was wrapped in foil and immediately frozen until analysis for chlorophyll. Aliquots of filtrate were kept refrigerated or stored if necessary frozen (DIN only) until analysis for dissolved inorganic $\mathrm{N}$ (DIN $=\mathrm{NH}_{4}{ }^{+}+$ $\mathrm{NO}_{3}{ }^{-}+\mathrm{NO}_{2}^{-}$) and dissolved inorganic (soluble reactive) $\mathrm{P}$ (DIP). All sample-processing containers were either rinsed well with deionized water or rinsed with $10 \% \mathrm{HCl}$ and deionized water between uses.

Phytoplankton samples were counted for cell numbers and heterocysts in a $5 \mathrm{ml}$ counting cell at $100 \times$ and $400 \times$ on a Wild M-40 inverted microscope. Samples were concentrated by gravitational settling or diluted with cell-free water as necessary (Wetzel \& Likens 2000). Because cell and heterocyst abundances spanned 3 to 4 orders of magnitude over time and the data showed regular heteroscedascity, numbers were log-transformed before statistical analysis to equalize variance and properly weight the data over time
(1 added to all numbers <10, Steel \& Torrie 1981). To focus the analysis of treatment effects, time-weighted treatment means of log-transformed cell and heterocyst abundances for each experiment were calculated as derived variables (Diggle et al. 1994). Simple analysis of variance (ANOVA) was used to determine treatment significance levels.

Chlorophyll a (chl a) concentrations were determined with a Turner Designs Model 10 fluorometer after pigment extraction in methanol (Holm-Hansen \& Riemann 1978). The assay was standardized spectrophotometrically using methanol solutions of pure chl $a$ and appropriate extinction coefficients. The $\mathrm{N}_{2}$-fixation potential was assayed periodically during Expts 1 \& 3 on integrated water-column samples using the acetylene reduction (AR) technique, modified to introduce the acetylene as a saturated solution in $0.2 \mu \mathrm{m}$ filtered seawater (Marino 2001). Mesozooplankton were concentrated from weekly samples, using 73 or $100 \mu \mathrm{m}$ nets (capture efficiency of adults plus copepodites and nauplii $>99 \%$ for both; Chan 2001). Details of the zooplankton sampling, preservation, and counting techniques are described in Chan et al. (2006).

Water-column TN and TP were measured colorimetrically as $\mathrm{NO}_{3}{ }^{-}+\mathrm{NO}_{2}{ }^{-}$or DIP after persulfate oxidation (Koroleff 1983) using a microwave digestion (CEM Instruments MDS 2000) at $150^{\circ} \mathrm{C}$ for $30 \mathrm{~min}$. DIN and DIP were measured in duplicate on a Lachat Instruments Quik Chem 8000 flow injection analyzer. Stored particulate algal material and bottom floc samples were thawed, freeze-dried, weighed, and ground finely with a mortar and pestle under liquid N. Particulate $\mathrm{N}$ and $\mathrm{C}$ were measured on a Carlo Erba NA 1500 CHN analyzer; particulate P was measured colorimetrically after combustion and hot $\mathrm{HCl}$ extraction (Marino 2001).

Bulk atmospheric deposition samples were collected in an acid-washed stainless steel bucket with a large funnel at the top; the collection apparatus was located on a platform $5.7 \mathrm{~m}$ above ground within $50 \mathrm{~m}$ of the mesocosms. The bucket was emptied and rinsed daily with $\mathrm{HCl}$ and deionized water. Samples were transferred into polypropylene bottles and frozen until analysis for DIN, DIP, TN, and TP as described above. Rain volume for each event was measured using a gauge mounted near the collector.

\section{RESULTS}

In all 3 experiments, planktonic, heterocystous cyanobacteria grew in the moderately high salinity estuarine water of the mesocosms (Fig. 1). The dominant cyanobacterium in all 3 yr was a filamentous, het- 


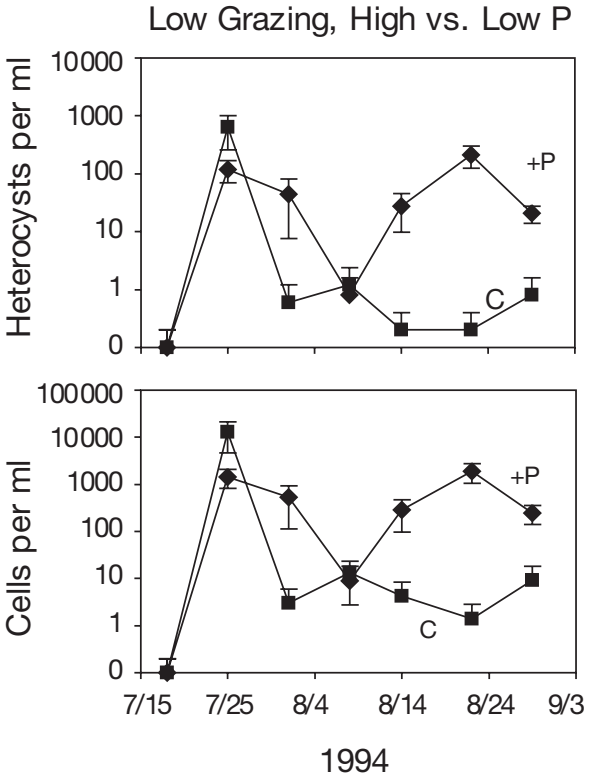

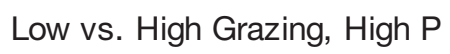
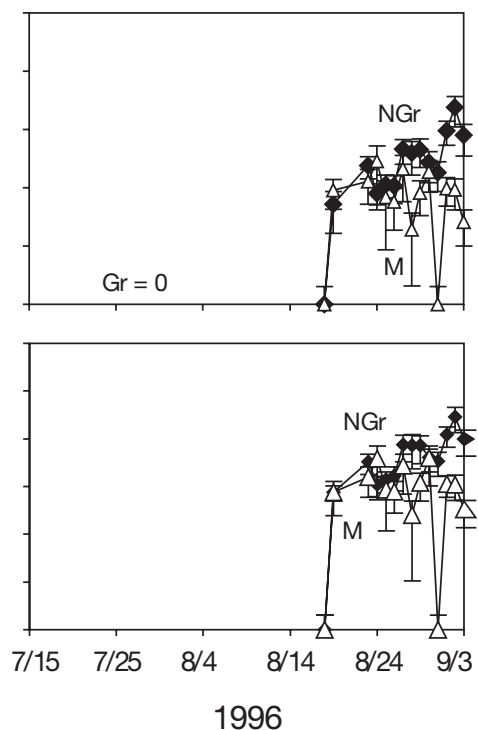

Low vs. High Grazing, High P
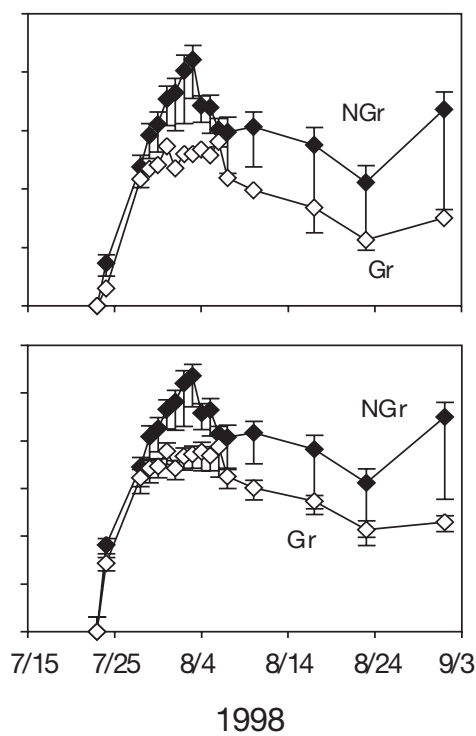

Fig. 1. Anabaena spp. Heterocyst (upper panels) and cell (lower panels) abundances over time during seawater mesocosm Expts 1 (1994), 2 (1996), and 3 (1998). Treatment means ( \pm 1 SE) are plotted for each sampling date. In 1994, C ( $\mathbf{1})$ denotes Control (i.e. no $\mathrm{P}$ addition) and +P $(\bullet)$ denotes P added. Grazing potential was low in both treatments. In 1996 and $1998, \mathrm{NGr}(\bullet)$ denotes low zooplankton grazing potential and $\operatorname{Gr}(\diamond)$ denotes high grazing potential. M $(\Delta)$ in 1996 denotes mussels added

erocystous type morphologically similar to Anabaena oscillarioides, a species found in a variety of littoral and pelagic freshwater habitats (Carr \& Whitton 1982). A Nodularia species was also observed in low abundance in 1 mesocosm (NGr) in Expt 3. Heterocysts, the active site of $\mathrm{N}$ fixation in both Anabaena and Nodularia species, were present in all 3 experiments for 2 to $5 \mathrm{wk}$ and were highly correlated with cell numbers (Fig. 1). Heterocyst numbers are often correlated with N-fixation rates (e.g. Levine \& Lewis 1987, Howarth et al. 1993, Findlay et al. 1994), and a sustained presence in the mesocosms provides strong evidence of active $\mathrm{N}$ fixation.

Nitrogenase activity, measured periodically during the experiments as AR, spanned 2 orders of magnitude and showed high variation among replicates, in part because heterocyst densities had already peaked and heterocyst numbers tended to be low $\left(<200 \mathrm{ml}^{-1}\right.$ for $90 \%$ ) for several of the dates the assay was run. Mean AR rates above detection (95\% CI > blank) normalized to heterocyst abundance ranged from 42 to $470 \times$ $10^{-15}$ mol ethylene heterocyst ${ }^{-1} \mathrm{~h}^{-1}$ and were $370 \times$ $10^{-15}$ mol ethylene heterocyst ${ }^{-1} \mathrm{~h}^{-1}$ or greater when heterocyst numbers were reasonably high. These values are within the range reported for freshwater systems (Howarth et al. 1993, Findlay et al. 1994). Peak AR rates of 500 to $1000 \times 10^{-15} \mathrm{~mol}$ ethylene heterocyst ${ }^{-1} \mathrm{~h}^{-1}$ have been reported in low-salinity areas of the Baltic Sea and the Peel-Harvey Estuary during blooms, though rates per heterocyst can vary by a factor of 5 or more within an individual study (Lindahl \& Wallstrom 1985, Huber 1986, Wasmund et al. 2001). Our AR data, while limited, confirm the potential for $\mathrm{N}_{2}$ fixation at high rates under some conditions in the mesocosms.

In Expt 1 (1994), where grazing was eliminated in both treatments, the addition of $\mathrm{P}(+\mathrm{P})$ had a clear and highly significant effect on abundance of both heterocysts and cyanobacterial cells (Fig. 1, Table 1). After an initial increase in heterocyst and cell numbers on 25 July in both treatments, cyanobacterial populations were sustained only in $+\mathrm{P}$ (Fig. 1). Control tanks had extremely low DIP throughout the experiment compared to $+\mathrm{P}$ (Fig. 2), which likely affected the ability of cyanobacteria to grow and produce heterocysts, as these organisms have a high $\mathrm{P}$ requirement relative to other algae (Fogg 1987). The DIP concentrations maintained in the $+\mathrm{P}$ mesocosms during Expt 1 (Fig. 2) were not unusual for Narragansett Bay (Nixon et al. 1980, 1995). In Expts 2 \& 3, all treatments received $P$ loads equivalent to $+\mathrm{P}$ in Expt 1, and DIP remained within or above the range for Narragansett Bay during the peak growing season (Fig. 2).

The presence of zooplankton (Gr) in Expts 2 \& 3 (1996 \& 1998) had a significant negative effect on both heterocyst and cyanobacterial cell numbers (Fig. 1, Table 1). Zooplankton abundances in $\mathrm{Gr}$ in both years averaged approximately 45 ind. $\mathrm{l}^{-1}$ (predominantly Acartia tonsa), a value well within the range observed in Narragansett Bay (Durbin \& Durbin 1981). In contrast, abundances in tanks with fish present (all tanks 
Table 1. Simple factorial ANOVA of heterocyst abundance and of water-column increase in total nitrogen (TN) during the 3 mesocosm experiments. Standard errors are in parentheses. Units are: heterocysts, weighted mean (log counts per ml), see 'Materials and methods'; water-column TN change $(\mu \mathrm{MN})$. TN changes were calculated as the difference between the final and initial values for each treatment, uncorrected for the $\mathrm{N}$ addition due to atmospheric inputs (see Fig. 2 and 'Materials and methods'). Similar levels of significance result when linear regression slopes of TN concentration over time are used as the derived variable. Note that heterocyst abundance for the 1998 experiment was analyzed for 2 time periods

\begin{tabular}{|c|c|c|c|c|c|c|c|}
\hline \multirow{2}{*}{$\begin{array}{l} \\
1994 \text { experiment } \\
\text { (all NGr) }\end{array}$} & \multirow{2}{*}{$\begin{array}{c}\text { ANOVA } \\
\text { (dependent variable) }\end{array}$} & \multicolumn{3}{|c|}{ Treatment mean (SE) } & \multirow[t]{2}{*}{$\mathrm{df}$} & \multirow[t]{2}{*}{$F$} & \multirow[t]{2}{*}{$\mathrm{p}$} \\
\hline & & Control & $+\mathbf{P}$ & & & & \\
\hline & Heterocyst abundance & $0.420(0.101)$ & $1.06(0.134)$ & & $(1,8)$ & 14.6 & 0.005 \\
\hline & Water-column TN change & $23.6(3.96)$ & $54.5(7.01)$ & & $(1,8)$ & 14.8 & 0.005 \\
\hline \multirow[t]{7}{*}{$\begin{array}{l}1996 \text { experiment } \\
(\text { all }+ \text { P) }\end{array}$} & & NGr & Gr & Mussels & & & \\
\hline & Heterocyst abundance & $1.19(0.382)$ & $0(0)$ & & $(1,6)$ & 9.63 & 0.021 \\
\hline & & - & $0(0)$ & $0.638(0.246)$ & $(1,6)$ & 6.71 & 0.041 \\
\hline & & $1.19(0.382)$ & - & $0.638(0.246)$ & $(1,6)$ & 1.45 & 0.271 \\
\hline & Water-column TN change & $28.7(5.94)$ & $23.4(3.23)$ & - & & 0.605 & 0.466 \\
\hline & & - & $23.4(3.23)$ & $25.9(5.58)$ & $(1,6)$ & 0.143 & 0.719 \\
\hline & & $28.7(5.94)$ & - & $25.9(5.58)$ & $(1,6)$ & 0.120 & 0.741 \\
\hline \multirow[t]{4}{*}{$\begin{array}{l}1998 \text { experiment } \\
(\text { all }+\mathrm{P})\end{array}$} & & NGr & Gr & & & & \\
\hline & $\begin{array}{l}\text { Heterocyst abundance } \\
\text { through } 17 \text { Aug }\end{array}$ & $1.34(0.152)$ & $0.920(0.094)$ & & $(1,12)$ & 4.99 & 0.045 \\
\hline & through 6 Sep (end) & $1.10(0.205)$ & $0.694(0.071)$ & & $(1,12)$ & 3.33 & 0.093 \\
\hline & Water-column TN change & $83.2(11.1)$ & 34.9 (6.99) & & $(1,12)$ & 16.5 & 0.002 \\
\hline
\end{tabular}

in 1994, NGr in 1996 \& 1998) averaged 0.5 to 1.1 ind. $\mathrm{I}^{-1}$. No cyanobacteria were detected in Gr in 1996. Both cyanobacterial cells and heterocysts were detected in Gr in 1998, but abundances were much lower than in NGr, where zooplankton densities were generally $<2$ animals $1^{-1}$, as in Expts 1 \& 2 (Chan et al. 2006). During the last 2 wk of Expt 3 (24 August to 6 September) there was a spiked increase in the calanoid copepod, A. tonsa in 3 of the $8 \mathrm{NGr}$ tanks (20 to 120 ind. $\mathrm{l}^{-1}$ ), although the cause of this late bloom is unclear. Nutrient concentrations (Fig. 2) and phytoplankton biomass did not have any clear response to the increase in zooplankton. Considering that heterocyst numbers might respond quickly to a newly introduced grazing pressure, we analyzed for a grazing treatment effect in Expt 3, using both the entire data set and the data collected prior to the zooplankton increase only (Table 1). In both cases, there was a significant effect of grazing treatment on the abundance of heterocysts, which is consistent with integrated measures of $\mathrm{N}$ fixation as discussed below. There was an interesting, though not statistically significant, trend toward reduced cyanobacterial cell and heterocyst numbers in Expt 2 when a benthic filter feeder was added after zooplankton were removed (+Mussels vs. NGr treatment, Fig. 1, Table 1). The duration of the cyanobacterial response in this experiment was short, with the effect of mussels most pronounced in the last $4 \mathrm{~d}$ of the experiment, and tankto-tank variance in cell and heterocyst numbers was large during the abbreviated period when Anabaena were present (Fig. 1).

The timing and duration of the cyanobacterial response in the mesocosms varied from year to year. While cyanobacteria in comparable treatments (low grazing and $\mathrm{P}$ enriched) responded similarly in 1994 (+P) and 1998 (NGr), cyanobacteria appeared much later in the season in the 1996 experiment ( $\mathrm{NGr}$, Fig. 1). Cooler, cloudier weather during July and early August in 1996 may have delayed growth and heterocyst formation. The mean temperature in the tanks during 1996 was $24.9^{\circ} \mathrm{C}$ and did not go above $24^{\circ} \mathrm{C}$ until after 16 August. In contrast, in both 1994 and 1998, the mean temperature during each experiment was $26.4^{\circ} \mathrm{C}$, and the means for July through 17 August were 26.5 and $28.5^{\circ} \mathrm{C}$, respectively. As temperature and cloud cover are related, PAR availability over most of 1996 was likely lower than in 1994 or 1998. Light intensity influences the ratio of active heterocyst to resting cell (akinete) formation in cyanobacteria, though it is unclear how differences in the light environment and/or temperature might affect heterocystous cyanobacterial growth and $\mathrm{N}_{2}$ fixation over a 

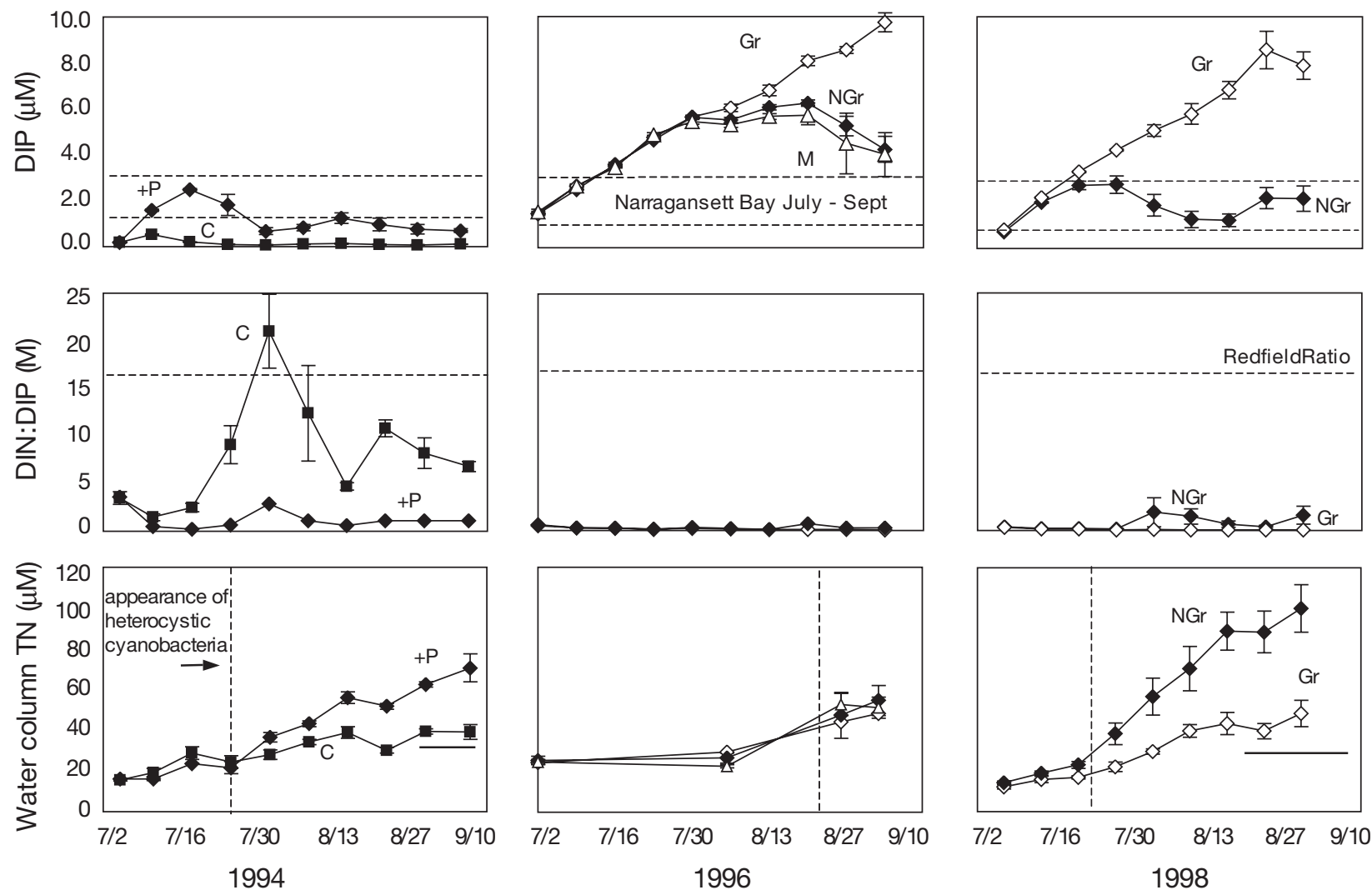

Fig. 2. Dissolved inorganic phosphorus (DIP, upper panels), dissolved inorganic nitrogen:dissolved inorganic phosphorus ratio (DIN:DIP, middle panels), and water-column total nitrogen (TN) increase (lower panels) for seawater mesocosm Expts 1, 2, and 3. Treatment means $( \pm 1 \mathrm{SE})$ are plotted for each sampling date $(\mathrm{mm} / \mathrm{dd})$. Symbols and abbreviations are as described for Fig. 1. Dashed lines on DIP plots indicate upper and lower range for Narragansett Bay during summer; dashed vertical line on watercolumn TN plots indicates appearance of heterocystous cyanobacteria. Horizontal solid line on water-column TN (1994, 1998) indicates initial TN plus cumulative TN added in deposition

growing season (Wyman \& Fay 1987, Levine \& Schindler 1992, Findlay et al. 1994).

Temporal patterns in DIP in the mesocosms differed across treatments and experiments as well, and were related to the magnitude and duration of cyanobacterial cells and heterocysts in the water column. As noted above, DIP concentrations were very low in Control and fairly low in $+\mathrm{P}$ in Expt 1 relative to the same treatment (NGr) in Expt 2 (Fig. 2). In Expt 3, DIP levels in NGr were similar to those in $+\mathrm{P}$ in Expt 1 (Fig. 2), as expected, since both manipulations were the same (low grazing, P-enriched) and had cyanobacteria present for similar periods (Fig. 1). DIP concentrations in Gr during Expt 3 gradually increased to much higher levels than in NGr (Fig. 2), and were inversely related to the differences in cyanobacterial abundances in the treatments (Fig. 1). In Expt 2, DIP gradually increased over time in all treatments, and reached particularly high levels in Gr (Fig. 2), where cyanobacteria were absent during the entire experiment. The higher DIP concentrations in $\mathrm{NGr}$ in Expt 2 relative to those observed in Expts 1 \& 3 likely reflect both the later appearance of cyanobacteria and the lower number of cells over time (Fig. 1). These DIP patterns suggest that heterocystous cyanobacteria are mediating removal of $\mathrm{P}$ from the water column, either by direct uptake or by providing a labile $\mathrm{N}$ input to the tanks, which then allows for further growth of other species among the highly N-limited phytoplankton. A combination of these 2 mechanisms is most likely.

The DIN:DIP ratio was always well below the Redfield ratio of 16:1 in P-enriched mesocosms (Fig. 2), providing conditions extremely favorable for $\mathrm{N}$ fixation in freshwater (Flett et al. 1980, Howarth et al. 1988b). For $+\mathrm{P}$ in Expt 1 and for all treatments in Expts 2 \& 3 (which received $\mathrm{P}$ loadings as in $+\mathrm{P}$ ), the DIN:DIP ratios were generally $<1: 1$ (Fig. 2). These DIN:DIP ratios are driven largely by DIP concentrations. DIN concentrations remained low and fairly constant in all experiments, at approximately 0.5 to $1 \mu \mathrm{M}$, and there were no significant treatment differences in DIN in any experiment (data not shown, Marino 2001).

The TN in the water column increased over initial levels in all treatments and experiments over the grow- 
ing season (Fig. 2). A portion of the water-column TN change in the tanks is due to the atmospheric deposition of $\mathrm{N}$, and, in Expt 1, the TN increase in the Control can be attributed almost entirely to this input (Fig. 2). The TN increase in the +P treatment in Expt 1 was significantly greater than in the Control (Table 1), and is presumably due to $\mathrm{N}$ fixation associated with a greater abundance of heterocysts and cyanobacterial cells (Fig. 1). We do not have data on the atmospheric deposition of $\mathrm{N}$ during Expt 2; however, it is likely that most of the water-column TN increase during that experiment was due to deposition, as cyanobacterial biomass and heterocyst numbers were low during most of that experiment. Accordingly, we did not find significant treatment differences in TN increase in Expt 2 (Fig. 2, Table 1). In Expt 3, the water-column TN increase was highly significant when zooplankton grazers were removed (NGr) and was much greater than the $\mathrm{N}$ input from atmospheric deposition (Fig. 2, Table 1). Again, we attribute this increase to a larger $\mathrm{N}$ input from $\mathrm{N}$ fixation associated with the greater abundance of cyanobacterial cells and heterocysts in NGr relative to Gr. The small water-column TN increase in Gr above that from atmospheric deposition is likely also due to $\mathrm{N}$ fixation (Fig. 2), but this input was clearly much less than in NGr. For both the 1994 and 1998 experiments, the rate of TN increase appears to accelerate in the P-addition, low-zooplankton treatments $(+\mathrm{P}, \mathrm{NGr})$ after heterocystous cyanobacteria appear (Fig. 2).

We constructed $\mathrm{N}$ budgets for each tank in Expt 3, allowing further exploration of the significance of the cyanobacteria as an $\mathrm{N}$ source to the mesocosms. In addition to the increase in water-column $\mathrm{TN}$, we accounted for $\mathrm{N}$ that accumulated in other forms, such as particulate $\mathrm{N}$. The input from $\mathrm{N}$ fixation is calculated as the excess TN present in the tanks [ $\Sigma$ final $\mathrm{N}$ pools $-(\Sigma \mathrm{N}$ initial pools $+\Sigma$ atmospheric $\mathrm{N}$ inputs $)]$. The specific pools quantified were: $\mathrm{TN}$ increase in the water column, TN removed in particulates (floating algal material and bottom floc), and net TN change in fish biomass. Net change in fish biomass in NGr over time was a trivial portion of the $\mathrm{N}$ budgets $(<1 \%)$ and is not considered further. Since all tanks were well oxygenated and did not stratify, we believe that denitrification was not a significant loss term in any of the budgets. Although we have no detailed data to quantify gaseous $\mathrm{NH}_{3}$ losses over time, we can estimate the relative importance of this term across treatments based on periodic measurements of $\mathrm{pH}$. In NGr tanks $\mathrm{pH}$ values of 8.7 to 9.2 were observed during peak hours of sunlight (10:00 to 14:00 EDST), whereas in Gr tanks the $\mathrm{pH}$ stayed $<8.4$. All tanks returned to seawater $\mathrm{pH}$ values of 8.2 to 8.3 during hours when photosynthesis was low. If $\mathrm{NH}_{3}$ were being volatilized to a significant extent, the overall $\mathrm{N}$ loss due to this pro- cess would be greater in NGr tanks, since $\mathrm{pH}$ values were higher during peaks of photosynthesis. Hence, the assumption of no $\mathrm{NH}_{3}$ loss for the $\mathrm{N}$ budgets is conservative in that we may have underestimated the importance of $\mathrm{N}$ fixation in $\mathrm{NGr}$ relative to $\mathrm{Gr}$. An analysis of treatment effect on the complete $\mathrm{N}$ budget indicates a highly significant main effect of grazing $(\mathrm{p}=0.0002)$ on total $\mathrm{N}$ input attributed to biological $\mathrm{N}$ fixation, with NGr having a mean TN increase over twice that of Gr (Fig. 3).

As a check on the accuracy of the sampling and analytical digestion procedures used to construct the nitrogen budgets, we also constructed $\mathrm{P}$ budgets for each tank by summing the various $\mathrm{P}$ pools as for N. For P, there are no gaseous flux terms, the cumulative experimental addition can be determined accurately (24.8 mmol $\mathrm{P}$ tank $^{-1}$ ), and the total input of $\mathrm{P}$ from atmospheric deposition $\left(0.17 \mathrm{mmol} \mathrm{P} \operatorname{tank}^{-1}\right)$ is very small. The $\mathrm{P}$ budgets, expressed as mean percent $\mathrm{P}$ recovered, balanced to within $5 \%(\mathrm{Gr}=98.6 \pm 2.8$; $\mathrm{NGr}=94.9 \pm 3.0$ ). These mean recoveries and the associated standard errors $(n=8)$ are quite acceptable, especially given the multiple sample collections and analyses, providing support for our $\mathrm{N}$ budgets.

\section{DISCUSSION}

Heterocystous cyanobacteria have not been reported in the plankton of estuaries that are persistently saline $(>10 \mathrm{ppt})$, yet our findings indicate these organisms can grow and fix $\mathrm{N}$ in a near-full-salinity seawater system (27 to $32 \mathrm{ppt}$ ) under some conditions. The dominant cyanobacterium in our mesocosms was Anabaena, 1 of 3 genera of heterocystous N-fixing cyanobacteria that form large blooms in the phytoplankton of mesotrophic and eutrophic lakes (Carr \& Whitton 1982, Whitton \& Potts 2000). Anabaena spp., as well as Nodularia and Aphanizomenon species, are common in the Baltic Sea, where salinity is generally $<10$ to 12 ppt (Lindahl \& Wallstrom 1985, Moisander et al. 2003, Stal et al. 2003). In those few estuaries where cyanobacterial blooms initiate when the salinity is very low and then persist as the salinity increases, Nodularia spp. dominate (Huber 1986, Jones et al. 1994, Pérez et al. 1999). The major N-fixing cyanobacterium in oceanic waters is a colonial, non-heterocystous form (Trichodesmium), found almost exclusively in warm, oligotrophic regions (Fogg 1987, Karl et al. 2002).

We observed strong control by zooplankton on cyanobacterial cell and heterocyst numbers, and on $\mathrm{N}$ accumulation in our mesocosms over time (Figs. 1, 2). Thus, abundances of mesozooplankton characteristic of an estuary such as Narragansett Bay were sufficient to greatly suppress cyanobacterial populations in our 


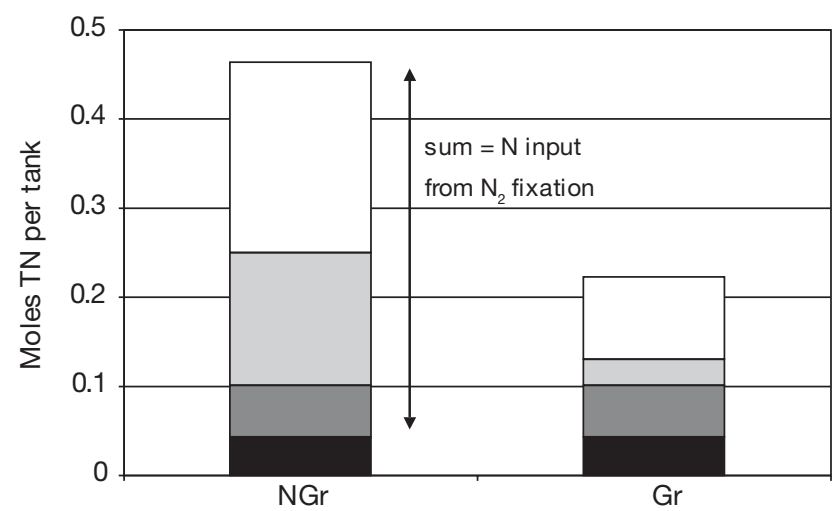

Fig. 3. Mean TN increase for the 1998 mesocosm experiment for Gr and NGr treatments. Stacked bars are treatment means for each $\mathrm{N}$ pool. White: water-column TN increase, exclusive of $\mathrm{N}$ input from deposition; light grey: $\mathrm{N}$ removed in floating algal/particulate material; dark grey: $\mathrm{N}$ in bottom floc/detritus at the end of the experiment; black: $\mathrm{N}$ input in atmospheric deposition; other abbreviations see Fig. 1. Treatment differences are significant at $\mathrm{p}<0.0002$

experiments. Work in freshwater ponds indicates that zooplankton can exert some control on cyanobacterial abundance (Schaffner et al. 1994, Hansson et al. 1998). Heterocystous cyanobacteria are particularly susceptible to grazing control (compared to other phytoplankton), as many photosynthetic cells are necessary to support $\mathrm{N}$ fixation in a heterocyst (Howarth et al. 1999, Chan et al. 2004). When grazing shortens or breaks up filaments, the potential for $\mathrm{N}$ fixation is greatly reduced, and population growth under N-limiting conditions is constrained. Acartia spp., including A. tonsa, the dominant zooplankton species in our experiments, can graze on heterocystous cyanobacteria (MeyerHarms et al. 1999). Short-term assays done during Expt 3 demonstrated $A$. tonsa grazed on the cyanobacteria present in these mesocosms (Chan et al. 2006).

While feeding on filamentous cyanobacteria would not seem to be a good strategy for survival in estuaries, due to the general absence of these organisms in the plankton, Acartia spp. do graze on other chain-forming phytoplankton, such as the diatom Skeletonema costatum (Martin 1970). Thus, grazing on developing filaments of cyanobacteria may be incidental to grazing on chain-forming diatoms. Alternatively, Acartia spp. have been shown to discriminate between some types of food particles and can ingest high-protein foods preferentially (Cowles et al. 1988, Butler et al. 1989). In the pre-bloom stages of growth, cyanobacterial cells can accumulate $\mathrm{N}$-rich compounds in accessory pigments such as cyanophycin or in gas-vesicle membranes (Whitton \& Potts 2000), and so would be a high$\mathrm{N}$ food. However, the grazing studies by Chan et al. (2006) showed no selectivity for or against Anabaena relative to diatoms.
In a freshwater experiment, Elser et al. (2000) also found fewer cyanobacteria and less $\mathrm{N}$ fixation when zooplankton abundances were greater. They attributed this relation to an indirect effect of the zooplankton, differentially recycling $\mathrm{N}$ and $\mathrm{P}$ so as to make the nutrient stoichiometry of the water less conducive to $\mathrm{N}$ fixation (i.e. high DIN:DIP). We believe this mechanism was not important in our studies, and that grazing by the zooplankton was the dominant mechanism whereby the cyanobacteria were suppressed in the Gr treatments relative to NGr. Throughout our study, the molar DIN:DIP ratio remained consistently 5-fold or more below the phytoplankton need, as described by the Redfield ratio in both the Gr and NGr treatments (Fig. 2), suggesting highly favorable conditions for $\mathrm{N}$-fixing cyanobacteria. Inorganic $\mathrm{N}$ concentrations also remained quite consistent and low, and were not statistically different between treatments. However, DIP concentrations were substantially higher in the $\mathrm{Gr}$ treatments over time (Fig. 2). As higher DIP favors cyanobacterial blooms (Howarth et al. 1988b, Moisander et al. 2003), nutrient conditions in the treatments in which zooplankton were present (Gr) were, if anything, more conducive to $\mathrm{N}$ fixation.

Two important differences can explain why the water-column DIN:DIP ratio increased in the presence of zooplankton in the experiments of Elser et al. (2000), but not ours. First, zooplankton biomass did not increase over time in our experiments (Chan 2001, Chan et al. 2006), so there was no opportunity for differential accumulation of P. Second, the dominant zooplankton in the freshwater experiment, Daphnia spp., have a low body N:P in comparison to the Redfield ratio (Elser \& Hassett 1994, Elser et al. 2000). Therefore, as the population increased, Daphnia preferentially sequestered $\mathrm{P}$ and elevated the DIN:DIP ratio of the water above the Redfield ratio. In contrast, the dominant zooplankton species in our experiments, Acartia tonsa, has a body N:P that is similar to the Redfield ratio (Walve \& Larsson 1999). Thus, if zooplankton populations had increased over time in the Gr treatment, the effect would have been to maintain or further lower the already low water-column N:P ratio, not raise it as in the freshwater experiment (Elser et al. 2000).

Zooplankton could also alter the water-column DIN:DIP through differential regeneration of $\mathrm{N}$ and $\mathrm{P}$ as microbial excretion products or material from sloppy feeding. The net effect on the Gr treatment would be to increase the already excess DIP supply relative to DIN, as organic $\mathrm{P}$ generally cycles more rapidly than organic N (Capblancq 1990, Vitousek \& Howarth 1991). This effect may have contributed to the increasing DIP concentrations observed in the Gr treatments. In any case, such preferential regeneration of $\mathrm{P}$ in zooplankton excretion products or from sloppy feeding 
would again tend to favor $\mathrm{N}$ fixation in our Gr treatment relative to the NGr, not suppress it, as observed. Microzooplankton, which can increase in abundance when planktivorous fish reduce the mesozooplankton, can also promote faster P recycling (Capblancq 1990). In this case, we would expect an increase in the availability of $\mathrm{P}$ in NGr tanks relative to $\mathrm{Gr}$, which was not reflected in the weekly DIP data (Fig. 2). Such an effect, if present, is very unlikely to be a significant bias in our results, since DIP is already present is large excess (DIN:DIP consistently <3, often $<1$ ). Hence, we are confident in concluding that the primary mechanism whereby zooplankton suppressed cyanobacterial growth and $\mathrm{N}$ fixation in our experiments was direct grazing.

While not statistically significant, the results of Expt 2 suggest that filter-feeding mussels may also suppress cyanobacterial numbers and heterocysts (Fig. 1, Table 1). The potential impact of mussels on phytoplankton populations has been examined in estuaries of Prince Edward Island, Canada, where phytoplankton biomass was reduced by $50 \%$ or more due to mussel herbivory (Meeuwig et al. 1998). In freshwater ecosystems, grazing by zebra mussels (Dressina polymorpha) and other bivalves has been shown to decrease overall phytoplankton biomass as well as alter the structure of the plankton community and suppress populations of some species of $\mathrm{N}_{2}$-fixing cyanobacteria (Smith et al. 1998, Strayer et al. 1999). While the potential effect of benthic grazers, such as mussels, on cyanobacteria requires further study, these organisms may provide another important ecological interaction limiting the ability of cyanobacterial populations to develop and fix $\mathrm{N}$ in some coastal marine systems.

\section{Comparison with other estuarine mesocosm experiments}

We are aware of no previous mesocosm experiments with estuarine water at salinities $>10 \mathrm{ppt}$ that resulted in the growth of $\mathrm{N}$-fixing heterocystous cyanobacteria in the plankton. Oviatt et al. (1995) fertilized mesocosms at the Marine Ecosystems Research Laboratory (MERL) facility, also at Narragansett Bay, with comparable $P$ inputs. As with our results, DIP was never depleted from the water column of the P-addition treatments (levels of $\sim 2 \mu \mathrm{M}$ ), DIN levels remained low $(\leq 0.5 \mu \mathrm{M})$, and $\mathrm{N}$ remained limiting to primary production and phytoplankton biomass. Cyanobacterial $\mathrm{N}$-fixers were absent from the water column throughout the Oviatt et al. (1995) experiment, even under conditions of extreme $\mathrm{N}$ deficit (only $\mathrm{P}$ added, N:P of $0: 1$ ). We hypothesize that grazing prevented cyanobacterial populations from developing in the water column, as N-fixing cyanobacteria grew to some extent as periphyton attached to the walls of the mesocosms (Oviatt et al. 1995).

In another experiment using Narragansett Bay water, Taylor et al. (1995) fertilized seagrass-lagoon mesocosms similar in depth and volume to our meso-

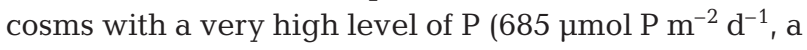
rate 4 -fold greater than in our experiments). Once again, as we observed (Fig. 2), DIP accumulated in the water column of the P-addition treatments (up to $7 \mu \mathrm{M})$, while the DIN concentration and the DIN:DIP ratio remained extremely low (Taylor et al. 1995). No heterocystous cyanobacteria were detected in the water column of the lagoon mesocosms (S. Nixon pers. comm.), and $\mathrm{N}$ limitation was maintained throughout the P-addition experiment, except in mesocosms where $\mathrm{N}$ fertilizer was also added (Taylor et al. 1995). The lagoon mesocosms had water-column and benthic communities modeled after those in natural systems of southern Rhode Island, including 2 species of benthic filter feeders (Taylor et al. 1995). Again, grazing may have played a significant role in excluding planktonic cyanobacteria from these systems.

The MERL experiment and the lagoon mesocosms of Taylor et al. (1995) both included sediments, whereas ours did not. The rate of $\mathrm{P}$ fertilization used in our experiments (all treatments except the 1994 Control) was similar to the P flux from sediments to the water column of Narragansett Bay in summer (Nixon et al. 1980), and sediments in these other mesocosm experiments also undoubtedly contributed $\mathrm{P}$ to the water column. Thus, the total input of $\mathrm{P}$ to the water column in these other estuarine mesocosms was likely substantially higher than in ours. The P loading in our experiments represented well the internal loading and concentrations typical of Narragansett Bay during the summer season.

Although the experimental systems in the 3 estuarine, nutrient-addition studies discussed above differed in morphometry and ecological complexity, some of the key responses were the same. In all cases, phytoplankton primary production remained $\mathrm{N}$ limited, and the $\mathrm{N}$ deficits induced by moderate to high $\mathrm{P}$ inputs and low N:P-loading ratios were not alleviated by blooms of heterocystous cyanobacteria in the plankton. Planktonic N-fixing cyanobacteria were observed only in our mesocosms, and not in those in which natural communities of grazers were present (Oviatt et al. 1995, Taylor et al. 1995).

\section{Comparison with freshwater experiments}

Even though cyanobacteria grew and fixed $\mathrm{N}$ in the plankton of our mesocosms when grazing pressure 
added ('Fish') or absent ('No Fish'). This experiment was replicated in $1000 \mathrm{~m}^{2}, 2 \mathrm{~m}$ deep ponds $(\mathrm{n}=4)$, fertilized with $\mathrm{P}$ at a slightly lower loading rate than used in our mesocosms (Table 2). When zooplankton grazing was low (Fish), heterocysts averaged $34400 \mathrm{ml}^{-1}, 2$ to 3 orders of magnitude greater than the mean abundance in our estuarine mesocosms. Grazing in the CEP experiment (No Fish) decreased cyanobacterial abundance, but mean numbers were still as high as we observed even without zooplankton (NGr) in estuarine mesocosms, and orders of magnitude higher than when grazers (Gr) were present (Table 2), despite comparable zooplankton densities in the No Fish and Gr treatments. As with the freshwater mesocosm experiment (Howarth et al. 1993), chl a levels were far higher in the CEP under low grazing conditions than in any of the estuarine mesocosms. Despite similar P loading, DIP concentrations were far lower in the CEP experiment than in either of the mesocosm experiments (Table 2), probably due to sediment uptake in the former.

A comparison of heterocyst and phytoplankton biomass responses to high $\mathrm{P}$ and low external N:P loading with whole-lake experiments done at the ELA shows a pattern similar to that seen in the direct comparison of the freshwater and saline mesocosm experiments described above. In a long-term, P-fertilization experiment at Lake 227, heterocyst numbers averaged between 1800 and $3470 \mathrm{ml}^{-1}$ from 1975 to 1989 and 1990 to 1992, respectively (Schindler 1977, Findlay et al. 1994). Fish populations were not manipulated over this time period, so this lake probably experienced zooplankton grazing pressure intermediate between the Fish and No Fish treatments at CEP or our mesocosm NGr and Gr treatments. The mean heterocyst abundances in Lake 227 during the summer season were an order of magnitude higher than the abundances we observed under a 'best case' scenario for reducing grazing mortality (i.e. NGr). The P loading to Lake 227 was similar to but somewhat lower than in our estuarine mesocosms (Table 2), yet, as with the other freshwater experiments discussed here, chl a levels were far higher (Table 2).

\section{Relative controls on planktonic $\mathbf{N}$ fixation}

The above comparisons clearly illustrate that at comparable $\mathrm{P}$ loadings and $\mathrm{N}$ deficiencies, the cyanobacterial responses in freshwater experimental systems are far greater than in our estuarine mesocosms or in the other marine mesocosm experiments. Thus, while heterocystous cyanobacteria could grow in the plankton and fix $\mathrm{N}$ in our saline estuarine mesocosms when grazing levels were kept low, conditions for growth and $\mathrm{N}$ fixation were far less optimal than in freshwater.
The marked contrast in the freshwater and marine experimental results (Table 2) supports the hypothesis of a fundamental difference in the response of seawater and freshwater planktonic systems when there is high $\mathrm{P}$ availability and $\mathrm{N}$ limitation of primary production (Howarth et al. 1988b, 1999, NRC 2000). Heterocystous cyanobacteria do not respond to high nutrient, low N:P conditions in saline estuaries by producing conspicuous blooms that fix significant quantities of $\mathrm{N}$ and help alleviate $\mathrm{N}$ limitation, as they often do in freshwater.

The strong contrast between our estuarine mesocosms and freshwater systems (Table 2) suggests that a systematic difference in $\mathrm{P}$ availability is not likely to be responsible for the dichotomy between the presence of heterocystous cyanobacteria in N-deficient freshwater and the general lack thereof in estuaries. Dissolved inorganic P levels, while variable across aquatic systems, are often higher by an order of magnitude or more in estuaries than in temperate zone lakes (Billen et al. 1991, Howarth et al. 1995), and yet heterocystous cyanobacteria are consistently absent from the plankton of higher salinity estuaries. While cyanobacterial growth rates are influenced by the supply of available P (Karl et al. 2002, Moisander et al. 2003), as supported by the results of Expt 1, cyanobacterial vegetative cell-growth rates in our seawater experiments under consistently high DIP concentrations were clearly not sufficient to initiate filamentous $\mathrm{N}$-fixer blooms to the extent observed in freshwater (Chan et al. 2006).

A variety of factors beyond those we focused on in this study can influence growth and $\mathrm{N}$ fixation by cyanobacteria in lakes and in the oligohaline Baltic Sea (see reviews by Howarth et al. 1988b, Paerl 1996, Hyenstrand et al. 1998, Paerl \& Zehr 2000). For example, in shallow hypereutrophic lakes, cyanobacteria can access high DIN concentrations below the euphotic zone by regulating buoyancy using a specialized morphology (gas vacuoles), giving them a competitive advantage over other types of phytoplankton even when they are not fixing $N$ (Ferber et al. 2004). Turbulence is an example of an important physical control on $\mathrm{N}$ fixation. Cyanobacterial blooms in lakes and the Baltic Sea frequently occur when the water column is relatively calm (Paerl 1985, Fogg 1987, Kononen et al. 1996). The tendency for blooms to occur during calm water has been interpreted as an adverse physiological effect of mixing and turbulent shear on cyanobacteria (Paerl 1985, Moisander et al. 2002b). However, Howarth et al. (1993) found high numbers of cyanobacteria with heterocysts and high rates of $\mathrm{N}$ fixation at very high turbulence in freshwater mesocosms of the same depth and volume as those used in this study. One alternative explanation for a lack of cyano- 
bacterial blooms in more turbulent water bodies is that these systems tend to have more deeply mixed surface waters, such that cyanobacteria are more constrained by another important physical factor, light (Levine \& Lewis 1987, Howarth et al. 1993).

While the $\mathrm{N}$-fixing activity of planktonic cyanobacteria is subject to numerous controls, few of these represent fundamental differences between freshwater and marine systems. Consider the control by mixing and light limitation, for example. While deeper mixing adversely affects N-fixing cyanobacteria in both Lake Valencia and the oligohaline regions of the Baltic Sea, abundant $\mathrm{N}$-fixers nonetheless occur in both of these systems, even when the depth of the mixed surface layer is $10 \mathrm{~m}$ or more (Levine \& Lewis 1987, Kononen et al. 1996). Similarly, at the time of high $P$ loadings to Lake Erie and Lake Washington, measurable rates of planktonic N fixation were observed in Lake Washington (Tison et al. 1977) and moderately high rates occurred in Lake Erie (Mague \& Burris 1973), even though the surface mixed layers in both lakes were $10 \mathrm{~m}$ or more. Deeply mixed water columns are also not generally characteristic of estuaries, and, hence, it is unlikely that $\mathrm{N}$-fixing cyanobacteria are absent from most saline estuaries for this reason. For example, of the 138 estuaries in the global data base of the LOICZ program, $68 \%$ have mean depths $<10 \mathrm{~m}$ and $36 \%$ have mean depths $<3 \mathrm{~m}$ (Smith et al. 2003). Some of these systems are well mixed, but others are stratified, and, hence, the mixed layers of the stratified systems are even shallower. Clearly if mixing depth and light availability were the major controls on the distribution of planktonic N-fixing cyanobacteria, these organisms would be expected to be much more common in shallow estuaries.

Freshwater experimental studies (Schaffner et al. 1994, Chan et al. 2004) have suggested that a grazing effect on cyanobacterial blooms may be greatest when cyanobacteria are growing slowly. Our results from this study and previous work suggest that a plausible general mechanism for excluding blooms of heterocystous $\mathrm{N}$-fixing cyanobacteria from the plankton of saline estuaries may be the interaction of grazing with 2- to 3-fold slower growth rates associated with higher sulfate concentrations relative to freshwater (Howarth et al. 1999, Marino et al. 2002). We have found that sulfate at typical seawater concentrations (24 to $28 \mathrm{mM}$ ) slows Anabaena-growth and N-fixation rates compared to those observed at freshwater sulfate concentrations, likely due to an inhibitory effect of sulfate on the uptake of Mo, which is not fully reversible (Cole et al. 1993, Marino et al. 2003). In the oligohaline regions of estuaries, the lower sulfate concentrations would reduce the physiological constraint on rapid cyanobacterial growth necessary for bloom initiation.

\section{Considerations for eutrophication management in estuaries}

This series of mesocosm experiments shows clearly that heterocystous, $\mathrm{N}$-fixing cyanobacteria can grow planktonically at relatively high salinities in estuaries. While a continuous supply of $\mathrm{P}$ was required, both cell and heterocyst abundances were low relative to comparable freshwater experiments, strongly suggesting that available concentrations of $\mathrm{P}$ and $\mathrm{a}$ favorable $\mathrm{N}: \mathrm{P}$ ratio are not sufficient to stimulate large blooms of pelagic cyanobacteria and subsequent inputs of $\mathrm{N}$ to estuarine systems, as is often the case in nutrient-enriched freshwater. Grazing by zooplankton at population densities that are characteristic of temperate zone estuaries, such as Narragansett Bay, greatly suppressed cyanobacterial cell numbers, heterocysts, and $\mathrm{N}$ fixation. Our data, while not conclusive, further suggest that grazing by benthic filter-feeding animals may also suppress cyanobacterial bloom development in estuaries. These findings underscore the potential importance of benthic-pelagic interactions and seasonal cycles of herbivores and nutrients with regard to controls on $\mathrm{N}$ fixation by planktonic organisms in estuaries, and how these might change as anthropogenic alteration of the coastal zone accelerates (NRC 2000, Paerl \& Zehr 2000). Comparative analysis of our results with other marine and freshwater experiments offers some insight into the relationship of the $\mathrm{N}$-fixation potential with $\mathrm{P}$ loading and availability in estuaries and how it differs from that in freshwater, where eutrophication control strategies based on reducing $\mathrm{P}$ inputs have been well established (NRC 2000). That planktonic $\mathrm{N}$ fixation in estuarine ecosystems is not generally of sufficient magnitude to alleviate $\mathrm{N}$ shortages and maintain $\mathrm{P}$ limitation of primary production and eutrophication over the time scales observed in freshwater ecosystems confirms the value in reducing $\mathrm{N}$ inputs to estuaries as a control strategy to reduce eutrophication.

Acknowledgements. We gratefully acknowledge the use of facilities and assistance of many staff and faculty members at the University of Rhode Island, especially B. Buckley, S. Granger, S. Nixon, and M. Pilson. The U.S. EPA laboratory in Narragansett, RI, provided some of the mesocosm tanks and the fish for the experiments, and we thank N. Jaworski and staff members. T. Butler, S. Tartowski, K. Kolberg, D. Pelletier, S. Robbins, M. Watson, S. Sherwood, B. Kopp, and D. Fischer provided invaluable help in the field and laboratory. This research was supported by grants from the National Science Foundation (NSF) and by an endowment given to Cornell University by David R. Atkinson. Fellowship support to F.C. was provided by NSF-sponsored graduate training grants. 


\section{LITERATURE CITED}

Billen G, Lancelot C, Meybeck M (1991) N, P, and Si retention along the aquatic continuum from land to ocean. In: Mantoura RFC, Martin JM, Wollast R (eds) Ocean margin process for global change. John Wiley \& Sons, Chichester, p 19-44

Butler NM, Suttle CA, Neill WE (1989) Discrimination by freshwater zooplankton between single algal cells differing in nutritional status. Oecologia 78:368-372

Capblancq J (1990) Nutrient dynamics and pelagic food web interactions in oligotrophic and eutrophic environments: an overview. Hydrobiologia 207:1-14

Carr NG, Whitton BA (1982) The biology of cyanobacteria. University of California, Berkeley, CA

Chan FC (2001) Planktonic nitrogen fixation: insights on ecological controls and cross-ecosystem patterns. PhD thesis, Cornell University, Ithaca, NY

Chan F, Pace M, Howarth RW, Marino R (2004) Bloom formation in heterocystous nitrogen-fixing cyanobacteria: the dependence of colony size and zooplankton grazing. Limnol Oceanogr 49:2171-2178

Chan FC, Marino R, Howarth RW, Pace ML (2006) Ecological constraints on planktonic nitrogen fixation in saline estuaries. II. Grazing controls on cyanobacterial population dynamics. Mar Ecol Prog Ser 309:41-53 (this volume)

Cole JJ, Lane JM, Marino R, Howarth RW (1993) Molybdenum assimilation by cyanobacteria and phytoplankton in fresh and salt waters. Limnol Oceanogr 38:25-35

Cowles TJ, Olson RJ, Chisholm SW (1988) Food selection by copepods: discrimination on the basis of food quality. Mar Biol 100:41-49

Diggle PJ, Liang K-Y, Zeger SL (1994) Analysis of longitudinal data. Oxford University Press, Oxford

Durbin AG, Durbin EG (1981) Standing stock and estimated production rates of phytoplankton and zooplankton in Narragansett Bay, Rhode Island. Estuaries 4:24-41

Elser JJ, Hassett RP (1994) A stoichiometric analysis of the zooplankton-phytoplankton interaction in marine and freshwater ecosystems. Nature 370:211-213

Elser JJ, Sterner RW, Galford AE, Chrzanowski RHand 5 others (2000) Pelagic C:N:P stoichiometry in a eutrophied lake: responses to a whole-lake food-web manipulation. Ecosystems 3:293-307

Ferber LR, Levine SN, Lini A, Livingston GP (2004) Do cyanobacteria dominate in eutrophic lakes because they fix atmospheric nitrogen? Freshw Biol 49:690-708

Findlay DL, Hecky RE, Hendzel LL, Stainton MP, Regehr GW (1994) Relationship between $\mathrm{N}_{2}$-fixation and heterocyst abundance and its relevance to the nitrogen budget of Lake 227. Can J Fish Aquat Sci 51:2254-2266

Flett RJ, Schindler DW, Hamilton RD, Campbell NER (1980) Nitrogen fixation in Canadian Pre-Cambrian shield lakes. Can J Fish Aquat Sci 37:494-505

Fogg GE (1987) Marine planktonic cyanobacteria. In: Fay P, Van Baalen C (eds) The cyanobacteria. Elsevier, Amsterdam, p 393-414

Hansson LA, Annadotter H, Bergman E, Hamrin SF and 6 others (1998) Biomanipulation as an application of food-chain theory: constraints, synthesis, and recommendations for temperate lakes. Ecosystems 1:558-574

Holm-Hansen O, Riemann B (1978) Chlorophyll a determination: improvements in methodology. Oikos 30:438-447

Howarth RW, Marino R, Lane JM, Cole JJ (1988a) Nitrogen fixation in freshwater, estuarine, and marine ecosystems. 1. Rates and importance. Limnol Oceanogr 33:669-687
Howarth RW, Marino R, Cole JJ (1988b) Nitrogen fixation in freshwater, estuarine, and marine ecosystems. 2. Biogeochemical controls. Limnol Oceanogr 33:688-701

Howarth RW, Butler T, Lunde K, Swaney D, Chu CR (1993) Turbulence and planktonic nitrogen fixation: a mesocosm experiment. Limnol Oceanogr 38:1696-1711

Howarth RW, Jensen HS, Marino R, Postma H (1995) Transport to and processing of phosphorus in near-shore and oceanic waters. In: Tiessen H (ed) Phosphorus in the global environment. SCOPE 54, Wiley \& Sons, Chichester, p 323-345

Howarth RW, Chan F, Marino R (1999) Do top-down and bottom-up controls interact to exclude nitrogen-fixing cyanobacteria from the plankton of estuaries: explorations with a simulation model. Biogeochemistry 46:203-231

Huber AL (1986) Nitrogen fixation by Nodularia spumigena Mertens (Cyanobacteriaceae). 1. Field studies and the contribution of blooms to the nitrogen budget of the PeelHarvey Estuary, western Australia. Hydrobiologia 131: 193-203

Hyenstrand P, Blomqvist P, Pettersson A (1998) Factors determining cyanobacterial success in aquatic systems - a literature review. Arch Hydrobiol Spec Issues Adv Limnol 51:41-62

Jones GJ, Blackburn SI, Parker NS (1994) A toxic bloom of Nodularia spumigena Mertens in Orielton Lagoon, Tasmania. Aust J Mar Freshw Res 45:787-800

Karl D, Michaels A, Bergman, B, Capone D and 6 others (2002) Dinitrogen fixation in the world's oceans. Biogeochemistry 57/58:47-98

Kononen K, Kuparinen J, Mäkelä K, Laanemets J, Pavelson J, Nõmmann S (1996) Initiation of cyanobacterial blooms in a frontal region at the entrance to the Gulf of Finland, Baltic Sea. Limnol Oceanogr 41:98-112

Koroleff K (1983) Determination of nutrients. In: Grasshoff K, Ehrhardt M, Kremling K (eds) Methods of seawater analysis, 2nd edn. Verlag Chemie, Weinheim

Levine SN, Lewis WM Jr (1987) A numerical model of nitrogen fixation and its application to Lake Valencia, Venezuela. Freshw Biol 17:265-274

Levine SN, Schindler DW (1992) Modification of the N:P ratio in lakes by in situ processes. Limnol Oceanogr 37:917-935

Lindahl G, Wallstrom K (1985) Nitrogen fixation (acetylene reduction) in planktonic cyanobacteria in Oregrundsgrepen, SW Bothnian Sea. Arch Hydrobiol 104:193-204

Mague TH, Burris RH (1976) Biological nitrogen fixation in the Great Lakes. BioScience 32:236-239

Marino RM (2001) An experimental study of the role of phosphorus, molybdenum, and grazing as interacting controls on planktonic nitrogen fixation in estuaries. PhD thesis, Cornell University, Ithaca, NY

Marino R, Howarth RW, Shamess J, Prepas EE (1990) Molybdenum and sulfate as controls on the abundance of nitrogen-fixing cyanobacteria in saline lakes in Alberta. Limnol Oceanogr 35:245-259

Marino R, Chan F, Howarth RW, Pace M, Likens GE (2002) Ecological and biogeochemical interactions constrain planktonic nitrogen fixation in estuaries. Ecosystems 5:719-725

Marino R, Howarth RW, Chan F, Cole JJ, Likens GE (2003) Sulfate inhibition of molybdenum-dependent nitrogen fixation by planktonic cyanobacteria under seawater conditions: a non-reversible effect. Hydrobiologia 500:277-293

Martin JH (1970) Phytoplankton-zooplankton relationships in Narragansett Bay. IV. The seasonal importance of grazing. Limnol Oceanogr 15:413-418

McCarthy J (1980) Nitrogen. In: Morris I (ed) The physiological ecology of phytoplankton. Blackwell Scientific Publications, Oxford, p 191-233 
Meeuwig JJ, Rasmussen JB, Peters RH (1998) Turbid waters and clarifying mussels: their moderation of empirical chl:nutrient relations in estuaries in Prince Edward Island, Canada. Mar Ecol Prog Ser 171:139-150

Meyer-Harms B, Reckermann M, Voß M, Siegmund H, von Bodungen B (1999) Food selection by calanoid copepods in the euphotic layer of the Gotland Sea (Baltic Proper) during mass occurrence of $\mathrm{N}_{2}$-fixing cyanobacteria. Mar Ecol Prog Ser 191:243-250

Moisander PH, McClinton E III, Paerl HW (2002a) Salinity effects on growth, photosynthetic parameters, and nitrogenase activity in estuarine planktonic cyanobacteria. Microb Ecol 43:432-442

Moisander PH, Hench JL, Kononen K, Paerl HW (2002b) Small-scale shear effects on heterocystous cyanobacteria. Limnol Oceanogr 47:108-119

Moisander PH, Steppe TF, Hall NS, Kuparinen J, Paerl HW (2003) Variability in nitrogen and phosphorus limitation for Baltic Sea phytoplankton during nitrogen-fixing cyanobacterial blooms. Mar Ecol Prog Ser 262:81-95

Niemi Å (1979) Blue-green algal blooms and N:P in the Baltic Sea. Acta Bot Fenn 110:57-61

Nixon SW, Kelly JR, Furnas BN, Oviatt CA, Hale SS (1980) Phosphorus regeneration and the metabolism of coastal marine bottom communities. In: Tenore KR, Coull BC (eds) Marine benthic dynamics. University of South Carolina, Columbia, SC, p 219-242

Nixon SW, Granger SL, Nowicki BL (1995) An assessment of the annual mass balance of carbon, nitrogen, and phosphorus in Narragansett Bay. Biogeochemistry 31:15-61

NRC (National Research Council) (2000) Clean coastal waters: understanding and reducing the effects of nutrient pollution. National Academy Press, Washington, DC

Oviatt CA, Doering P, Nowicki B, Reed L, Cole J, Frithsen J (1995) An ecosystem level experiment on nutrient limitation in temperate coastal marine environments. Mar Ecol Prog Ser 116:171-179

Paerl HW (1985) Microzone formation: its role in the enhancement of aquatic $\mathrm{N}_{2}$ fixation. Limnol Oceanogr 30:1246-1252

Paerl HW (1996) A comparison of cyanobacterial bloom dynamics in freshwater, estuarine and marine environments. Phycologia 35:25-35

Paerl HW, Zehr JP (2000) Marine nitrogen fixation. In: Kirchman DL (ed) Microbial ecology of the oceans. Wiley-Liss, Chichester, p 387-426

Pérez MC, Bonilla S, de Léon L, Smarda J, Komárek J (1999) A bloom of Nodularia baltica-spumigena group (Cyanobacteria) in a shallow coastal lagoon of Uruguay, South America. Algol Stud 93:91-101

Schaffner WR, Hairston NG Jr, Howarth RW (1994) Feeding rates and filament clipping by crustacean zooplankton consuming cyanobacteria. Verh Internat Verein Limnol 25:2375-2381

Schindler DW (1977) Evolution of phosphorus limitation in lakes. Science 195:260-262

Editorial responsibility: Otto Kinne (Editor-in-Chief), Oldendorf/Luhe, Germany
Sellner KG (1997) Physiology, ecology, and toxic properties of marine cyanobacteria blooms. Limnol Oceanogr 42: 1089-1104

Smith SV, Swaney DP, Talaue-McManus L, Bartley JD and 7 others (2003) Humans, hydrology, and the distribution of inorganic nutrient loading to the ocean. BioScience 53: 235-245

Smith TE, Stevenson RJ, Caraco NF, Cole JJ (1998) Changes in phytoplankton community structure during the zebra mussel (Dressina polymorpha) invasion of the Hudson River (New York). J Plankton Res 20:1567-1579

Stal L, Albertano P, Bergman B, von Brockel K, Gallon JP, Hayes PK, Sivonen K, Walsby AE (2003) BASCI: Baltic Sea cyanobacteria. An investigation of the structure and dynamics of water blooms of cyanobacteria in the Baltic Sea-response to a changing environment. Cont Shelf Res 23:1695-1714

Steel RGD, Torrie JH (1981) Principles and procedures of statistics. A biometrical approach, 2nd edn. MacGraw-Hill, Singapore

Strayer DL, Caraco NF, Cole JJ, Findlay S, Pace ML (1999) Transformation of freshwater ecosystems by bivalves. BioScience 49:19-27

Taylor D, Nixon SW, Granger S, Buckley B (1995) Nutrient limitation and the eutrophication of coastal lagoons. Mar Ecol Prog Ser 127:235-244

Tison DL, Palmer FE, Staley JT (1977) Nitrogen fixation in lakes of the Lake Washington drainage basin. Water Res 11:843-847

Tracey GA (1988) Feeding reduction, reproductive failure, and mortality in Mytilus edulis during the 1985 'brown tide' in Narragansett Bay, Rhode Island. Mar Ecol Prog Ser 50:73-81

Vitousek PM, Howarth RW (1991) Nitrogen limitation on land and in the sea. How can it occur? Biogeochemistry 13: $87-115$

Walve J, Larsson U (1999) Carbon, nitrogen, and phosphorus stoichiometry of crustacean zooplankton in the Baltic Sea: implications for nutrient cycling. J Plankton Res 21: $2309-2321$

Wasmund N, Voss M, Lochte K (2001) Evidence of nitrogen fixation by non-heterocystous cyanobacteria in the Baltic Sea and recalculation of a budget of nitrogen fixation. Mar Ecol Prog Ser 214:1-14

Wetzel RG, Likens GEL (2000) Limnological analyses, 3rd edn. Springer-Verlag, New York

Whitton BA, Potts M (eds) (2000) The ecology of cyanobacteria. Their diversity in time and space. Kluwer, Dordrecht

Wyman M, Fay P (1987) Acclimation to natural light climate. In: Fay P, Van Baalen C (eds) The cyanobacteria. Elsevier, Amsterdam, p 348-376

Zehr JP, Waterbury JB, Turner PJ, Montoya JP, Omoregie E, Steward GF, Hansen A, Karl DM (2001) Unicellular cyanobacteria fix $\mathrm{N}_{2}$ in the subtropical North Pacific Ocean. Nature 412:635-638

Submitted: September 1, 2004; Accepted: August 21, 2005 Proofs received from author(s): January 27, 2006 